\title{
A constituição social da memória: lembranças de uma testemunha da II Guerra Mundial
}

\author{
The social constitution of memory: memories of a World War II witness \\ La constitución social de la memoria: memorias de un testigo de la $2^{a}$ Guerra \\ Mundial
}

\author{
Alice Casanova Reis* \\ Lia Vainer Schucman ${ }^{* *}$
}

\begin{abstract}
Resumo
Este artigo tem como objetivo investigar como se constitui a memória de uma testemunha da II Guerra Mundial. Para tanto, realizamos uma entrevista com um sujeito que nos relatou as lembranças de suas vivências durante a guerra. A partir da Psicologia social, em uma abordagem sócio-histórica, concebemos a memória como social e historicamente construída e como constitutiva da subjetividade do recordador. A análise identificou os núcleos de sentido presentes na narrativa da entrevistada por meio das seguintes categorias: memória coletiva nacional, memórialembrança e memória-hábito, memória como juízo sobre o passado, as ambiguidades da memória, memória e identidade judaica. Concluímos que a memória de Judite acerca da guerra é constituída através de uma apropriação singular daquela experiência coletiva, mediada por valores socioculturais, de grupo, de classe, aspectos ideológicos e vivências individuais.

Palavras-chave: memória; subjetividade; II Guerra Mundial; Psicologia social.
\end{abstract}

\begin{abstract}
This article aims to investigate how the memory of a World War II witness is constituted. For such, we interviewed a man who told us the memories of his experiences during the war. Based on Social Psychology, in a social and historical approach, we conceived memory as socially and historically constructed and as constitutive of the subjectivity of the one who remembers. The analysis identified the meaning cores present in the interviewee's
\end{abstract}

Doutoranda em Psicologia Social e do Trabalho pelo Programa de Pós-graduação em Psicologia do Instituto de Psicologia, Laboratório de Psicologia da Arte (Lapa), da Universidade de São Paulo (USP). E-mail: alicecasanova@yahoo.com.br.

Doutoranda em Psicologia Social e do Trabalho pelo Instituto de Psicologia da Universidade de São Paulo (USP). E-mail: liavainers@gmail.com. 
narrative through the following categories: national collective memory, remembrance-memory and habit-memory, memory as judgment of the past, ambiguities of memory, memory and Jewish identity. We concluded that the interviewee's memory of the war is shaped by a unique appropriation of that collective experience, mediated by social, cultural, group and class values, as well as ideological aspects and individual experiences.

Key-words: memory; subjectivity; World War II; Social psychology.

\section{Resumen}

Este artículo tiene como objetivo investigar cómo es la memoria de un testigo de la Segunda Guerra Mundial. Entrevistamos a una persona que nos relató los recuerdos de sus vivencias durante la guerra. Desde la Psicología Social, en la perspectiva socio histórica, concebimos la memoria como social e históricamente construida y, como constitutiva de la subjetividad de quien recuerda. El análisis identificó los núcleos de sentido presentes en la narrativa del entrevistado a través de las siguientes categorías: memoria colectiva nacional, memoria-recuerdo y memoriahábito, memoria como juicios sobre el pasado, las ambigüedades de la memoria, la memoria y la identidad judía. Llegamos a la conclusión de que la memoria de la entrevistada acerca de la guerra se hace a través de una apropiación singular de la experiencia colectiva, mediada por los valores socioculturales, grupos, clases, aspectos ideológicos y las experiencias individuales.

Palabras clave: memoria; subjetividad; Segunda Guerra Mundial; Psicología social.

\section{Pensando a memória}

0

estudo da memória é de fundamental importância à Psicologia social, pois o sujeito se constitui historicamente nas relações sociais e, nesse processo, a memória remete ao tempo vivido, cujo conjunto de experiências compóe um campo de sentidos para a construção de sua identidade. A identidade é aqui compreendida enquanto metamorfose, isto é, como movimento ou identificações em curso, designando "o processo de permanente transformação do sujeito humano, que se dá dentro de 
condições materiais e históricas dadas" (Ciampa, 1998, p. 88). Neste trabalho, desenvolvido em uma abordagem sócio-histórica, investigou-se de que modo se dá a constituição social da memória e do sujeito recordador a partir do testemunho pessoal de um fato histórico do século XX: a II Guerra Mundial.

A memória individual nos permite o acesso à História por uma via alternativa àquela da versão oficial e institucionalizada dos fatos, conduzindonos àquilo de que, em última análise, a história é feita: a vida cotidiana de sujeitos concretos. Para Agnes Heller (2000), o cotidiano está no centro do acontecer histórico, de modo que ele é a própria substância da história. No entanto, geralmente não há registros dessa cotidianidade de que a história é feita. Daí a importância da memória oral, pois, na narrativa de fatos vividos pelo recordador, podemos reencontrar o ponto de interseção entre a História e a vida de seus protagonistas. Na Psicologia social, o estudo da memória nos mostra que "Mais do que o documento unilinear, a narrativa mostra a complexidade do acontecimento. É a via privilegiada para chegar até o ponto de articulação da História com a vida cotidiana" (Bosi, 2003, p. 19).

A memória é um processo psicológico superior (Vygotski, 2000), semioticamente mediado por imagens, sentimentos e ideias, que constituem as lembranças do recordador, permitindo-lhe reportar-se ao tempo passado. A matéria da memória é a experiência vivida e, nesse sentido, a memória é subjetiva, porque ela resulta da apropriação singular de um sujeito sobre sua realidade objetiva, ou seja, sobre os fatos por ele protagonizados ou testemunhados. Contudo há também uma dimensão intersubjetiva na memória, uma vez que, na apropriação do vivido, aquilo que é retido pelo sujeito em forma de lembrança é mediado por significados socialmente compartilhados. Existe, portanto, uma função cognitiva da memória, já que ela advém de um conhecimento vivencial acerca do mundo, dos outros e de si mesmo.

Por meio da memória, o sujeito registra o presente, permitindo que ele não se perca, mas possa ser resgatado, acessado por meio da lembrança, presentificando o passado ao recordá-lo. A relação da memória com o tempo é complexa, pois a memória não apenas traz o passado à tona, mas também, ao fazê-lo, contribui na percepção do presente e também na construção do projeto de futuro do sujeito, revelando-se, com isso, sua importante função existencial.

Com base na teoria de Bérgson, Ecléa Bosi (2003) nos ajuda a compreender a influência da memória na percepção do presente, segundo a qual a memória 
poderia ser representada como um cone invertido. Na base do cone estariam as lembranças. $\mathrm{O}$ vórtice tocaria o plano do presente, onde os atos perceptuais se valem da totalidade da experiência adquirida para significar o que está sendo percebido no aqui-agora. Conforme explica a autora: "O cone da memória avança sem cessar para o futuro. Enquanto a percepção é a interseção do corpo com o mundo, a memória é a conservação que o espírito faz de si mesmo" (Bosi, 2003, p. 45).

Além do aspecto cognitivo, o afetivo também permeia a relação entre percepção e memória. Lembramos o que, de algum modo, foi-nos significativo, isto é, há uma base afetivo-volitiva influindo na atividade da memória. Essa base inclui nossas sensações, emoções e desejos, remetendo-nos ao papel do corpo como seara da memória. Nessa perspectiva, introduzimos o conceito de "corpo memorativo" (Bosi, 2003, p. 44), pois este evidencia que o corpo retém de algum modo os sentidos das experiências vividas pelo sujeito.

Esse papel fica claro quando estamos falando da "memória-hábito" (Bosi, 2003 , p. 38), por meio da qual o corpo conserva esquemas motores que fazem a mediação de comportamentos automáticos (por exemplo, dirigir um automóvel), mas também aparece no caso da memória-lembrança. $\mathrm{Na}$ lembrança, a atividade de rememoração mobiliza emocionalmente o sujeito mnêmico. A narrativa oral se produz, portanto, desde o discurso e do phatos do narrador, constituindo um verdadeiro trabalho sobre o tempo (Bosi, 2003). Por meio da narrativa, o sujeito dá voz ao passado, podendo reviver não somente os fatos vividos, mas também os sentimentos a eles associados. Por isso, relembrar é mais do que rever imagens esquecidas, é transportar-se até o interior delas e ser novamente por elas afetado, quanto mais nítidas forem.

Nessa complexa atividade da memória, o autor da narrativa coincide existencialmente com o seu sujeito. Esse aspecto é fundamental para compreendermos a função da memória na constituição da identidade. Ao falar sobre seu passado, o sujeito não apenas o lembra, mas também reflete sobre fatos, pessoas, momentos cruciais de sua existência, apropriando-se significativamente da sua história e ressignificando a si mesmo em função dela. Com isso, a narrativa se constrói como uma totalidade plena de sentidos, os quais contribuem para a constituição da identidade do narrador, com base no seu reconhecimento como autor e ator da história relatada.

\section{Adentrando a memória da testemunha}

Neste trabalho, investigamos a memória de Judite, uma senhora cuja 
juventude transcorreu na Iugoslávia, durante a II Guerra Mundial. A memória é um processo ativo que pode se objetivar de diferentes modos, entre os quais o depoimento. No depoimento, carregado de intencionalidade afetiva, o discurso resulta do trabalho da memória. Ao dar um depoimento, o sujeito relata suas lembranças, tornando acessível aos outros o conteúdo de sua memória. Por isso o método escolhido para colher o depoimento de Judite, no qual sua memória se expressa, foi a entrevista (Szymanski, 2000).

A entrevista realizada partiu de uma questão desencadeadora que convidava o sujeito a contar a sua história de vida durante a II Guerra Mundial $^{1}$. Seguindo o percurso indicado por Bosi (2003), algumas perguntas exploratórias foram introduzidas ao longo da narrativa pela entrevistadora, com o intuito de esclarecer ou aprofundar certos pontos, mas deixando a entrevistada praticamente livre para encadear os momentos do seu passado. Desse modo e ancoradas por Bosi (2003), entendemos que, na entrevista, ao depor sobre o passado, o sujeito se constitui como sua testemunha.

Judite é uma senhora de 84 anos, de classe média, socióloga aposentada, nascida em Belgrado, capital da Iugoslávia, em uma família de origem judaica. Tendo vivido na II Guerra Mundial, a ela sobreviveu para dela dar testemunho. Sua história foi marcada por diversas fugas com a família para diferentes países da Europa, passagens por campos de concentração e pela perda trágica de familiares e conhecidos, acontecimentos também vividos por tantos outros judeus durante aquele período. Depois da guerra, Judite veio para o Brasil com seus pais para reencontrar outros familiares que aqui tinham se refugiado, aqui se casou, teve filhos e netos, residindo atualmente em São Paulo.

A entrevista foi realizada na residência de Judite e teve duração de duas horas aproximadamente, sendo registrada por um gravador, com o consentimento da entrevistada. A entrevista é aqui concebida como um momento de interação dialógica entre sujeitos, ou seja, "um encontro interpessoal que inclui a subjetividade dos protagonistas e se constitui num momento de construção de um conhecimento novo, nos limites da representatividade da fala e na busca da horizontalidade nas relações de poder" (Szymanski, 2000, p. 197). Logo se entende que a qualidade do vínculo é

\footnotetext{
A Segunda Guerra Mundial (1939-1945) foi um conflito que envolveu a maioria das nações do mundo, divididas em duas alianças militares opostas: os Aliados (União Soviética, EUA, Inglaterra) e o Eixo (Alemanha, Itália, Japão). Foi a guerra mais abrangente da história, com mais de 100 milhōes de militares mobilizados. Marcado por um significante ataque contra civis, incluindo o Holocausto e a única vez em que armas nucleares foram utilizadas em combate, foi o conflito mais fatal da história da humanidade, com mais de 70 milhōes de mortos, entre os quais 6 milhões de judeus. A guerra acabou com a vitória dos Aliados (Disponível em <http://pt.wikipedia.org>).
} 
determinante à qualidade da entrevista (Bosi, 2003), o que foi facilitado pela mediação de uma pessoa conhecida de ambas: da entrevistadora e da entrevistada.

Após a entrevista, o depoimento de Judite foi imediatamente transcrito. Posteriormente, realizou-se sua análise, tendo como foco norteador a compreensão dos sentidos atribuídos por Judite à sua história durante a guerra. Com base na leitura exaustiva do material coletado, foram identificados e categorizados alguns núcleos de sentido constitutivos da memória da testemunha e de sua identidade como sujeito daquela história. Para tal análise, foi necessário observar o caráter histórico, cultural e fluido dos significados compartilhados pelo coletivo judaico acerca da experiência da guerra, embora eles possam ter sido ressignificados de modo singular pela entrevistada.

Procuramos compreender a memória de Judite, remetendo-nos ao contexto cultural e social em que se originaram suas lembranças. Assim, além de situar Judite no contexto histórico-social do Leste europeu durante a Guerra, devese mencionar sua condição de ser de uma família judia de classe alta naquele lugar e época, com todas as (im) possibilidades que essa condição representava. Assim, apesar de o depoimento ser singular, uma vez que reflete a memória de um sujeito, ele traz consigo elementos do coletivo, possibilitando uma generalização acerca do fato histórico considerado. Com isso, queremos defender a legitimidade do estudo do social desde o individual, porque todo singular se forja no coletivo das relaçôes sociais em que o sujeito está inserido, o que já fora suficientemente apontado por Vygotsky (1996): “O conhecimento do singular é a chave de toda a Psicologia social; de modo que devemos conquistar para a Psicologia o direito de considerar o singular, ou seja, o indivíduo como um microcosmo, como um tipo, como um exemplo ou modelo da sociedade" (p. 368). Destarte, reconhecendo essa complexa dialética que constitui o sujeito na interface entre o coletivo e o individual, compreendemos a construção social da memória de Judite conforme a análise a seguir apresentada.

\section{Memória coletiva nacional}

A fala do depoente emerge de sua memória desde as lembranças que, para ele, são as mais importantes. Na história de Judite durante a II Guerra, um dos momentos nitidamente gravados em sua memória remete ao início do envolvimento da Iugoslávia na Guerra. Na ocasião, recorda Judite:

Acontece a ascensão de Hitler, que invade a Áustria, e, quando ele invadiu a Áustria, aí a Iugoslávia sentiu politicamente um 
estremecimento no nacionalismo dela. Só que nós ainda achávamos que era um fato isolado que aconteceu com a Áustria, mas que não ia acontecer com os outros países, e de jeito nenhum com a Iugoslávia. O ministro de relações exteriores da Iugoslávia ia para Berlim para assinar um pacto com a Alemanha, um pacto de não beligerância com a Alemanha. E daí, para a população de Belgrado, foi um choque, porque isso implicava que a gente se aliava à Alemanha nas futuras invasóes e se tornava aliado dos alemães.

Nessa passagem do relato de Judite, percebemos o papel da memória coletiva na constituição das lembranças do sujeito. Por seu depoimento, Judite se torna porta-voz da experiência de um coletivo no qual está incluída: nós, a gente, ou seja, o povo de Belgrado. Destaca-se, com isso, o pertencimento do sujeito ao grupo social mais amplo, como cidadão iugoslavo, com todas as implicações políticas e sociais que dessa condição adviriam com a eclosão da Guerra.

Esse pertencimento também baliza a significação atribuída ao acontecido pelo sujeito, pois se pode notar o nacionalismo como valor ideológico presente em sua lembrança individual. A ideologia é aqui compreendida na acepção que lhe dá Marilena Chauí (1984): "É um 'fato' social justamente porque é produzida pelas relações sociais... uma certa maneira de produção de ideias pela sociedade, ou melhor, por formas históricas determinadas das relações sociais" (p. 31, grifo da autora). A ideologia, enquanto um conjunto de ideias que traduzem valores sociais, conforma os sujeitos a certa visão da realidade, apresentando-se como "um fenômeno objetivo e subjetivo involuntário produzido pelas condições objetivas da existência social dos indivíduos" (Chauí, 1984, p. 78).

Em Judite, o nacionalismo se expressa pela ideia coletiva, por ela compartilhada, de que seu país estaria imune à invasão da Alemanha. Posteriormente, quando isso não se confirmou, ela experimentou o sentimento coletivo de revolta, diante da ameaça da perda da autonomia nacional com seu país se aliando à Alemanha. Judite segue seu relato, contando sua participação em uma manifestação contrária à assinatura do pacto com os alemães, emocionando-se ao recordar esse fato:

E aí eu me lembro muito bem que todas as crianças de todas as escolas foram na estação de trem e deitaram assim nos trilhos do trem. Aliás, eu estou me comovendo [seus olhos se enchem de lágrimas] quando me lembro disso. Foi uma iniciativa da escola, liderada pelos professores, pois toda população tava contra. Foi 
realmente uma manifestação maravilhosa! Todas as crianças de todas as escolas de Belgrado, numa distância de vários quilômetros, deitaram nos trilhos e os trens não puderam sair. Foi um gesto muito comentado e, enfim, de fato a Iugoslávia acabou não fazendo esse pacto que, no fundo, influenciou, e não é pretensioso dizer, mas foi a primeira semente que influenciou toda política posterior da Iugoslávia em relação à Alemanha e, no fundo, foi por isso que os alemães bombardearam Belgrado, e bombardearam a Iugoslávia, e entraram na Iugoslávia sem nenhuma declaração de guerra.

$\mathrm{Na}$ época desse acontecimento, Judite era apenas uma criança (tinha então 9 anos). Entretanto se trata de uma recordação viva em sua memória, carregada de afetividade e mediada certamente pelo contexto social de que fazia parte como aluna de uma escola pública democrática. Destaca-se a importante dimensão política que Judite atribui à manifestação social de que fez parte, pois o protesto teria sinalizado o posicionamento da Iugoslávia como nação autônoma, gerando a retaliação pela Alemanha por meio de sua invasão ao país e bombardeio de Belgrado. Além disso, o significado simbólico do gesto de Judite e das demais crianças reforça e intensifica o seu sentido político-ideológico, representando o desejo nacionalista de impedir a aliança com a Alemanha, como se dissessem: "Acordo? Só passando por cima de nós!”.

Bosi (2003), ao discorrer sobre o papel do social na fixação das experiências infantis pela memória individual, pontua que "O conjunto das lembranças é também uma construção social do grupo em que a pessoa vive e onde coexistem elementos de escolha e rejeição em relação ao que será lembrado" (p. 54). Assim, analisamos que o sentido com que Judite reconstrói aquele fato em sua narrativa remete ao contexto cultural e institucional (a escola) em que estava então inserida, reconhecendo-se, em sua fala, esse imbricamento entre suas lembranças factuais e os valores do grupo que protagonizou aquele acontecimento histórico-político. Portanto, na lembrança daquele fato, entrevemos que Judite se constitui como testemunha da memória coletiva nacional.

\section{Memória-lembrança e memória-hábito}

Em determinado momento de sua narrativa, Judite relata a sua passagem por um campo de concentração na Albânia. Ela foi para lá enviada pelo exército italiano, juntamente com cerca de 300 judeus que estavam refugiados em Kotor, cidade iugoslava que fora então ocupada pelos italianos. 
E aí chegamos a Tirana, que é a capital da Albânia, e nos levaram para um campo de concentração duma cidade que chamava Kabaia, que já tinha um campo de concentração de militares, dos desertores italianos. E ali tinha um campo, que eu não sei nem se eu posso chamar de campo, eram dois galpóes enormes com beliches com palha e só. Aí eles separaram os homens das mulheres, e as condiçóes higiênicas eram miseráveis, era a pior coisa que podia acontecer, terrível. Puseram as pessoas para cavar fossas, porque não tinha fossas e aí é que começou a minha prisão de ventre, aí eu comecei a não ir ao banheiro, era tudo aberto, não tinha privacidade, era uma coisa horrível.

O confinamento em um campo de concentração durante a II Guerra foi certamente uma experiência traumatizante para todos os que por ela passaram. Isso não somente nos campos nazistas, marcados por uma rotina de extermínio de judeus, mas também naqueles nos quais a violência se exercia por meio das condições de precariedade extrema, da humilhação e desumanização que sujeitavam os prisioneiros, caso de nossa entrevistada. No campo de Albânia, a vida de Judite foi poupada, e ela nos conta, com pesar, que soube só posteriormente do genocídio sofrido pelos judeus em campos de extermínio como Auschwitz.

Com base nisso, pode-se analisar que a memória individual reconstrói o passado também por percepções e informações do sujeito posteriores ao acontecimento do fato e em consonância com o seu registro pela memória do grupo. Desse modo, uma vez que há um abismo entre a vivência do campo de concentração por Judite e o significado compartilhado na memória do coletivo judaico acerca dos campos da II Guerra Mundial, é como se Judite não se sentisse no direito de nomear sua experiência com o signo "campo", pois este está associado à morte trágica de seis milhões de judeus ${ }^{2}$. Por isso, ao relembrar o período vivido em Kabaia, Judite pontua: "Nós ficamos nessas condições seis meses, eram condições realmente muito precárias, mas eu preciso dizer que, em nenhum momento, houve assim perigo de vida, quer dizer a tua integridade física nunca foi ameaçada”.

Na memória-lembrança de Judite, a experiência vivida no campo aparece paradoxalmente como não ameaçadora, significado talvez emergente a partir da racionalização de sua vivência, em comparação com a memória coletiva do Holocausto. No entanto seu corpo, que vivia na carne aquelas precárias condições de existência, percebia seu entorno como uma ameaça eminente. E

\footnotetext{
2 A II Guerra Mundial exterminou não apenas judeus, mas também ciganos, polacos, homossexuais, portadores de deficiências, dissidentes políticos, etc. O holocausto foi posteriormente julgado pelo Tribunal de Israel como crime contra a humanidade.
} 
o aspecto traumatizante daquela situação, de algum modo, ficou registrado no corpo, em sua memória-hábito, como se evidencia no momento em que Judite remete a origem de seu problema físico de constipação à ausência de banheiro no campo. Sua recusa sistemática dessa necessidade fisiológica, visando a evitar o problema que para ela representava o seu exercício sem as mínimas condições de higiene e privacidade no campo, acabou por condicionar seu corpo. Se o medo provocado pela guerra não pode ser lembrado em ideia, sob pena de ser revivido, enquanto afeto ele está incorporado na memória corporal como hábito de não ir ao banheiro. A prisão de ventre, que persiste até hoje, é assim uma metáfora da prisão de Judite no campo, atualizando um sofrimento cuja lembrança permanece em determinada medida indizível.

\section{Memória como juízo sobre o passado}

O sujeito se constitui a partir da sua história, cujos acontecimentos são por ele apreendidos significativamente por meio da memória, mas também do esquecimento. Alguns fatos marcam profundamente a pessoa, modificando até mesmo alguns de seus valores. Isso aconteceu com Judite, como analisamos no trecho em que ela nos conta como se tornou ateia:

Meus avós não quiseram sair de Belgrado, porque tinham filhos prisioneiros de guerra na Alemanha. E, infelizmente, foram mesmo mortos pelos alemães os meus avós. E, aliás, desde então, eu sou totalmente ateia, realmente eu não acredito em nada, porque eu levei um tamanho choque quando soube que eles tinham morrido e em circunstâncias tão trágicas.

Entende-se que o olhar da testemunha acerca do vivido não é neutro, mas mediado por sentidos afetivos e valores sociais a partir dos quais reflete sobre seu passado. Assim, por meio de seu depoimento, o recordador pode também formular juízos acerca dos fatos de seu passado e das açōes dos outros, assim como das próprias. Segundo Asch (1966), o juízo ético baseia-se no sentimento compartilhado do que é certo e errado, avaliação que remete à adequação ou inadequação das ações individuais às exigências sociais. Segundo o juízo de Judite, a morte dos avós era uma grande injustiça, uma perda irrecuperável e injustificável sob qualquer ponto de vista, colocando em xeque sua crença em Deus ou em qualquer princípio divino de justiça.

Outro momento em que o trabalho da memória aparece como juízo sobre o passado é quando ela nos relata o modo como sua relação com a União Soviética foi modificada desde a posição assumida por aquele país na II Guerra: 
Antes de entrar na faculdade [fez faculdade em São Paulo], desde a Europa, na Suíça, eu fui até presa, porque eu pertencia aos movimentos de esquerda e eu tinha uma queda pelo socialismo. Mas aí depois eu até fui pra URSS quando foi o $20^{\circ}$ Congresso do $\mathrm{Kruschev}^{3}$, mas depois das várias coisas que aconteceram, depois dos massacres, aí eu não sei te explicar agora racionalmente, mas o próprio antissemitismo russo que me fez perder um pouquinho essa simpatia socialista. Mas ideologicamente eu realmente achava completamente injustificável um regime socialista fazer essa perseguição contra as minorias e aí especialmente contra os judeus.

Para Judite, o antissemitismo russo era incompatível com o socialismo, pois pressupunha a desigualdade entre os homens. A partir desse julgamento e da identificação solidária de Judite com os judeus perseguidos pela URSS, ela sente eticamente o dever de rever sua própria inclinação política ao socialismo, deixando clara sua desaprovação frente às ações do Estado russo. É preciso ter claro que, embora seja o Estado quem faça as leis, ele não é a origem da justiça, pois os regimes mais tirânicos podem construir leis que legitimam suas ações injustas (Asch, 1966). Tal é o caso dos Estados nazifascistas, por meio da homologação de leis como as de Nuremberg 5 , que legitimaram a perseguição aos judeus. E no juízo de Judite, não há razão que ampare os atos cometidos sob a ideologia antissemita.

\section{As ambiguidades da memória}

Em sua narrativa, a entrevistada se reportou diversas vezes à participação determinante do exército italiano nos acontecimentos por ela vividos durante a Guerra. Na ocupação da Iugoslávia, os italianos confiscaram a casa da família de Judite, acusaram e condenaram injustamente seus familiares e outros judeus por acreditarem que eles teriam financiado a Guerrilha Montenegrina (na qual tropas italianas foram assassinadas por guerrilheiros nacionalistas em Montenegro). Por isso eles foram enviados ao campo de Kibaia, na Albânia, de onde foram posteriormente transferidos para o campo de Ferramonte, na região italiana da Calábria. Apesar desses acontecimentos adversos, é num sentido predominantemente positivo que a memória oral de Judite reconstrói

\footnotetext{
Nikita Kruschev governou a URSS de 1956 a 1964, tendo se pronunciado no $20^{\circ}$ Congresso do Partido Comunista, em 1956, no qual denunciou os crimes de Stalin durante a II Guerra Mundial (Disponível em <http://www.marxists.org>).

4 As Leis de Nuremberg, aprovadas pela Alemanha em 1935, eram leis antissemitas que classificavam as pessoas com quatro avós alemães como "sangue alemão ou aparentado" e como judeus as pessoas que descendessem de três ou quatro avós judeus. Essas leis privaram os judeus da cidadania alemã e proibiram o casamento entre judeus e alemães (Disponível em $<$ http://pt.wikipedia.org>).
} 
as lembranças associadas aos italianos, como se pode perceber na seguinte passagem:

Aí entraram tanto alemães como os italianos, ocuparam a Iugoslávia. Aí o nosso apartamento já foi confiscado pelo Estado Maior Italiano, que, aliás, eu preciso dizer que eles foram extremamente decentes com a gente. Eles nos deram dois quartos, um banheiro, o apartamento era muito grande, e o uso eventual da cozinha. Mas, na época que nós estávamos lá, foi uma convivência absolutamente civilizada.

É interessante o modo como isso ficou registrado na memória de Judite: ela relativiza o fato de os italianos terem se apossado de sua residência, justificando que ela era muito grande e, ademais, além de concederem uma parte do apartamento aos seus moradores de direito, tornaram sua presença intrusiva tolerável por uma convivência percebida como civilizada pela narradora. Com certo estranhamento diante de tal relato, pergunto à Judite se ela estaria mesmo se referindo ao exército fascista7 italiano, o que ela confirma, mas com a seguinte ressalva:

Exatamente, quer dizer era o "Alto Comando Italiano", só o alto comandante que morava lá de fato, e todo dia tinha movimento do alto comando, mas quem morava lá mesmo era só o "big boss" do alto comando, e nós convivemos com eles um mês e meio, dois meses quase.

Analisamos aqui a ambiguidade da memória, pois, para Judite, os fatos são recordados por uma intrigante inversão: seu relato descreve os fatos de um modo tal que nos dá a entender que não foram os italianos que se apossaram da casa, mas seus donos, que lhes "emprestaram" o lar como sede provisória do Alto Comando. Nesse ponto, talvez seja interessante pontuar a presença de uma ideologia de classe, mediando a lembrança de sua convivência com os militares italianos como uma "convivência civilizada". Segundo Horkheimer e Adorno (1978), originalmente o termo civilização estaria associado à cultura do espírito, designando o âmbito geral da humanidade. Além disso, civilização também está associada à ideia de progresso, implicando uma concepção evolucionista da sociedade, a qual pode ser assim compreendida:

\footnotetext{
Segundo Paxton (2007), "O fascismo tem que ser definido como uma forma de comportamento político marcada por uma preocupação obsessiva com a decadência e a humilhação da comunidade, vista como vítima, e por cultos compensatórios da unidade, da energia e da pureza, nas quais um partido de base popular formado por militantes nacionalistas engajados, operando em cooperação desconfortável, mas eficaz com as elites tradicionais, repudia as liberdades democráticas e passa a perseguir objetivos de limpeza étnica e expansão externa por meio da violência redentora e sem estar submetido a restriçōes étnicas ou legais de qualquer natureza" (p. 359).
} 
Segundo os evolucionistas sociais, em todas as partes do mundo, a cultura teria se desenvolvido em estados sucessivos, caracterizados por organizações sociais e econômicas. Esses estágios, entendidos como únicos e obrigatórios... seguiam determinada direção, que ia sempre do mais simples ao mais complexo (Schwarcz, 1993, p. 57).

Qual era, na época, o modelo então julgado como o mais evoluído? Era justamente o europeu, sendo o preconceito social dirigido às minorias étnicas como judeus, ciganos, negros, etc. Segundo Crochik (2006): "O preconceito se remete à dominação e, quando é o caso, à proposta de eliminação do desconhecido para se manter aquilo que já é conhecido" (p. 115). Judite nasceu e cresceu na Europa, em uma família aristocrática, onde aspectos como a educação, as boas maneiras, as aparências, o conforto, o hedonismo e a civilidade eram alguns dos valores determinantes. Assim, Judite assimilou esses valores, identificando-se com a cultura europeia dominante. Além disso, sua família não praticava o judaísmo, de modo que ser judia foi uma condição não problematizada por ela até a eclosão da Guerra. Esses são aspectos que podem nos ajudar a compreender as ambiguidades da memória, graças ao que Judite não se recorda do exército italiano como seu inimigo. Essa compreensão é reforçada por outros momentos da narrativa de Judite, quando, por exemplo, ela relembra sua prisão e envio para o campo de concentração de Kabaia pelos italianos:

A Albânia foi ocupada pelos italianos, como a Grécia e parte da Iugoslávia. Então eles simplesmente nos prenderam, mas não havia violência. É que as condiçôes eram muito precárias, muito, muito. Mas, em nenhum momento, houve qualquer tipo de agressão física. Nada. Nada. Isso eu preciso dizer assim. Por isso que eu acho que tenho assim um reconhecimento pelos italianos, uma simpatia, eu diria quase um amor pelos italianos, porque, com tudo que eles foram aliados da Alemanha do Hitler, eles são outra gente.

O que mais chama atenção nessa passagem é a distinção com que Judite se recorda dos italianos: "eles são outra gente". A memória reflete as contradiçōes da substância social que a constitui: a partir de sua condição de classe, Judite identifica-se com os italianos; não quaisquer italianos, mas sim o "Alto Comando Italiano", como ela mesma especifica. Da sua condição social provém em parte o reconhecimento que, apesar de tudo, nutre pelos italianos. Entretanto, a negação da violência inerente às ações do exército de Mussolini tem raízes mais profundas: embora esteja ciente de que a Itália 
era aliada de Hitler, Judite está, de certo modo, ideologicamente alienada ${ }^{6}$ a partir dessa identificação de classe com os italianos e afetivamente alienada pelos sentimentos positivos que mediaram sua convivência com os italianos, configurando com eles uma relação de simpatia, "quase um amor"7.

A ambiguidade da memória em Judite se alicerça sobre sua identificação com a classe dominante, na qual Judite se encontrava até então e na qual permaneceria, caso não fosse judia, condição que, naquele momento histórico, veio para o primeiro plano, determinando sua exclusão daquele grupo e sua inclusão na massa de pessoas-alvo contra as quais o nazifascismo empreendeu sua "luta darwiniana" (Paxton, 2007, p. 360). Parece ter sido essa exclusão que mais causou sofrimento a Judite, porque isso teria alterado seu destino, conforme reflete a entrevistada:

Eu me sinto muito injustiçada. Injustiçada é a sensação que tive quando tive que ir embora da Europa, e eu continuei durante muito tempo e eu não sei se essa sensação não continuou, apesar de que eu casei, tive filhos aqui. Mas eu acho que se tivesse ficado lá, se não tivesse tido a Guerra, eu teria feito montes de coisas importantes. Eu escrevia super bem, apesar de ser pequena. $\mathrm{Na}$ escola e no colégio na Suíça, também eu sempre escrevia, fazia trabalhos muito bons, até que tinha uma promessa quase de jornalismo, isso que eu queria fazer. Apesar de ser pequena, lembro que eu tinha várias pretensões. Nesse sentido, eu acho que o meu destino mudou. Não sei, pode ser que tenha sido até melhor ou pior, eu nunca vou saber disso, mas, na minha fantasia, teria sido melhor.

Por esse trecho, analisamos que, na constituição social da memória de Judite, há uma relação de identificação e admiração com a cultura europeia, determinando o sentimento de pesar com que ela recorda sua fuga da Europa para o Brasil. Quando a entrevistada diz que, em sua fantasia, viver na Europa teria sido melhor, lembra com tristeza de um futuro por ela desejado, mas que, por causa da guerra, nunca chegou a se concretizar. A guerra arrancou-a do lugar de sujeito de sua história, sujeitando-a ao destino comum de tantos judeus expatriados. De um modo ambíguo, a entrevistada desloca a responsabilidade por isso dos Estados nazifascistas europeus para a condição judaica com a qual ela não se identificava, como analisaremos melhor adiante.

\footnotetext{
Para Chauí (1998), "A alienação é o fenômeno pelo qual os homens criam ou produzem alguma coisa... deixam-se governar por ela como se ela tivesse poder em si e por si mesma, não se reconhecem na obra que criaram, fazendo-a um ser-outro, separado dos homens, superior a eles e com poder sobre eles" (p. 170).

Essa relação positiva se fortaleceu quando Judite se apaixonou por um italiano, que, para o desgosto de sua família, foi seu primeiro namorado.
} 
A contradição apresentada por Judite na recordação de seu refúgio para o Brasil está ligada à sua ambivalência afetiva, pois, se por um lado, a Europa é o continente do qual foi desterritorializada10, por outro, ela representa os valores que mediaram o seu desenvolvimento intelectual e artístico desde a tenra infância. A Europa que, de certo modo, a expulsou é também a Europa das boas maneiras, a Europa da língua francesa, a Europa que toca piano e a Europa dos cavalheiros. Judite nos traz elementos que reiteram essa análise quando nos fala de sua educação na Suíça, após o término da guerra, remetendo-nos à importância daqueles valores na constituição de sua identidade: "E eu fui num colégio na Suíça que era o lugar mais grã-fino do mundo, onde eu aprendi a jogar tênis, a andar a cavalo, jogar polo, tocar piano e acabei toda a minha escolaridade".

Tais valores foram recebidos por Judite desde sua educação em uma cultura erudita, a qual, segundo distingue Alfredo Bosi (1992), cresce nas classes altas por meio do sistema escolar, sendo uma cultura individualizada e de difícil aprendizado, diferentemente da cultura popular, mais espontânea, relacionada ao folclore e caracterizada por sua gratuidade. Judite frequentou a Ecole Internationale na Suíça, recebendo uma educação acessível a poucos. E o pertencimento a essa cultura erudita é um dos aspectos desde os quais ela parece se distinguir dos demais judeus, embora tenha sido igualada a eles enquanto prisioneira e refugiada de guerra.

\section{Memória e identidade judaica}

Entendendo a identidade como processo de identificaçôes em curso (Santos, 1995), analisamos aqui de que modo a memória contribui na constituição da identidade judaica de Judite. Focamos, é claro, sua memória da guerra, buscando compreender de que modo a subjetividade se constitui desde as relaçóes com a alteridade, as quais foram mediadas fundamentalmente por significados históricos e sociais de ser judeu, apropriados por Judite por meio de sentidos singulares, que perfazem sua vivência pessoal da judaicidade.

Definir o que é o judaísmo e o que é ser judeu é o ponto nodal que está no bojo das discussões contemporâneas sobre identidade judaica. Nenhuma das categorias sociológicas, como religião, etnia, nação e raça, possibilita uma

\footnotetext{
8 Entendemos aqui o termo desterritorialização literalmente como a saída do território, com todas as implicaçōes subjetivas que esse movimento gera na constituição do sujeito, cuja identidade se vincula mais do que a um território geográfico, ao lugar simbólico delineado por um determinado locus social. Segundo Haesbaert (2004), haveria um sentido genérico de desterritorialização como destruição ou transformação de territórios (enquanto espaços ao mesmo tempo de dominação político-econômica e de apropriação simbólico-cultural) e um sentido mais estrito, vinculado à precarização territorial daqueles que perdem substancialmente os seus "controles" e, ou, identidades territoriais.
} 
compreensão exata do que é ser judeu. Para o rabino brasileiro Nilton Bonder (2001, p. 13), "A complexidade do judaísmo está em ser um pouco de tudo o que não é: não é religião, não é filosofia, não é cultura, não é etnia, não é estado e não é terra. É tudo ao mesmo tempo". Judite é filha de pai e mãe judeus e cresceu na comunidade judaica. No entanto, sua fala nos revela que ela não se identificava com nenhuma das categorias sociológicas citadas para definir o que é ser judeu:

Eu não tinha nenhum sentimento de pertencer à comunidade judaica, apesar de que eu tava sempre rodeada dela. A minha revolta era "Por que eu tenho que estar aqui?". Eu não tenho nada a ver com essa gente, eu tô compartilhando o destino deles, mas não tenho uma identidade com eles. É que eu não tive uma educação judaica. Isso é o erro de você pegar uma criança e não lhe dar uma identidade, não digo religiosa, mas pelo menos cultural. Nesse ponto de vista foi muito ruim para mim, muito.

Judite nos surpreende com a negação de sua identidade judaica, pois, em sua memória, os judeus são os outros: "Eu não tenho nada a ver com essa gente". Mesmo não se identificando com o grupo judaico, entretanto, essa identidade foi externamente atribuída a ela. Sua inclusão entre os judeus lhe é pontuada pela entrevistadora, que comenta o episódio que ela mesma acabara de contar, quando ela e os outros judeus foram obrigados, por ordem dos alemães, a usar uma faixa amarela no braço para se identificarem como tais, mas sua recusa permanece inabalável: "É, mas eu não tive nenhum sentimento de inclusão, eu tive um sentimento de revolta. 'Por quê? Eu não tenho nada a ver com isso!'. Não é uma coisa pertencente, entende”.

Em seu estudo acerca da identidade judaica, Schucman (2006) explica que o Estado nazista não definia alguém como judeu por suas crenças religiosas e práticas culturais; em vez disso, qualquer um que tivesse alguma ascendência judaica era definido como judeu, independentemente da própria identificação dos sujeitos à cultura judaica. Assim, muitas gerações de alemães que já não praticavam a tradição e a religião judaica foram definidas como judeus e levados aos campos de concentração.

Dessa forma, encontramos duas forças complementares na constituição da identidade judaica de Judite. A primeira, uma força externa a ela: o antissemitismo, que, além de unificar reativamente os judeus, também os apresenta como um grupo homogêneo, o que vai longe de refletir a realidade heterogênea do universo judaico. Não obstante o abismo imenso a separar uma ortodoxia religiosa de uma judaicidade laica, diferenciando no contexto concreto da vida diferentes modos de ser judeu, desde fora desse universo, o 
olhar externo e, principalmente, o olhar antissemita os unifica a todos como iguais (Schucman, 2006).

A outra força que incide na constituição da identidade judaica da entrevistada é justamente a memória de suas vivências na guerra, pois a perseguição aos judeus integra significativamente o conjunto das experiências do coletivo judaico ao longo da história. Michael Pollak (1989, p. 9) apresenta o lugar da memória na construção das identidades coletivas:

A memória, essa operação coletiva dos acontecimentos e das interpretaçōes do passado que se quer salvaguardar, se integra em tentativas mais ou menos conscientes de definir e de reforçar sentimentos de pertencimento e fronteiras sociais entre coletividade. A referência ao passado serve para manter a coesão dos grupos e das instituições que compõem uma sociedade, para definir seu lugar respectivo.

Portanto o substrato social da memória de Judite acerca da guerra a impele de se reconhecer objetivamente como parte do coletivo judaico, embora, em sua vivência subjetiva individual, não se sentisse como tal. Tanto é que o sentimento associado à lembrança de ter sido identificada como judia é a revolta. A faixa amarela é, para ela, um signo ideológico de humilhação.

Há várias formas de se constituir judeu, no entanto, no caso específico de Judite, o antissemitismo foi o que atribuiu exteriormente a ela essa identidade. Os casos como de Judite fizeram com que vários pensadores discutissem sobre a importância do antissemitismo na constituição da identidade judaica. Assim, para Sartre (1995), ser judeu não se constitui pela tradição, religião e cultura judaica, mas sim por uma situação antissemita que une os judeus.

A comunidade judaica não é nacional, nem internacional, nem religiosa, nem étnica, nem política, é uma comunidade quase histórica. O que faz o judeu é a situação concreta; o que o une a um outro judeu é a identidade de situação (p. 83).

O judeu é um homem que os outros homens consideram judeu: eis a simples verdade de onde se deve partir (p. 40).

Para o filósofo, o "problema judaico" desapareceria se o preconceito deixasse de existir, ou seja, a condição para a permanência do judaísmo é o antissemitismo. A posição de Sartre foi questionada por muitos teóricos judeus e não judeus, pois ele não deu atenção para a constituição dessa identidade pela força interna de coesão do grupo judaico. Porém cabe aqui lembrar que Sartre escreveu sobre essa questão logo após a Grande Guerra, quando realmente muitos sujeitos, como Judite, que já não faziam parte da 
comunidade judaica e não estabeleciam nenhuma relação com a tradição, foram mandados aos campos de concentração por serem "judeus".

Albert Memmi (1970) também fala da condição judaica em situação, termo claramente retirado da teoria sartreana. Em Retrato de um judeu, Memmi deixa claro que, para ele ser judeu, é uma condição objetiva, dada pela situação dos judeus na Diáspora, pela situação antissemita, de modo que essa condição judaica objetiva é algo irrecusável, é uma situação em que os sujeitos foram colocados sem opção de escolha. Em seu depoimento, Judite recorda o momento em que a situação dos judeus na Guerra foi apreendida por ela como determinante na sua identificação com o povo judaico:

Depois da Guerra, que a gente ouviu aquelas coisas terríveis dos campos de concentração, que a gente soube do pessoal que foi morto, dos familiares. A gente soube de todos aqueles horrores dos campos de concentração, aí pode ser realmente que eu tive, realmente eu levei um choque. Deve ter sido a minha primeira identificação solidária com o judaísmo.

Alain Finkielkraut (1981), em O judeu imaginário, diz que considerou, por muito tempo, a identidade judaica como um suceder de tragédias. $\mathrm{O}$ autor apresenta como tese a ideia de que a identidade judaica é uma identidade de memória, "porque se há efetivamente na 'judeidade' uma exigência, esta não deve ser pensada em termos de identificação, mas de memória" (p. 45). A tese do autor faz eco sobre a judaicidade construída pela entrevistada a partir da sua história, vivida e narrada. A história dos judeus é uma história de perdas sucessivas. Primo Levi, que passou por Auschwitz, relata com profundidade essa experiência, na qual as perdas objetivas se refletem subjetivamente como perda de si mesmo:

Agora imagine um homem que, além de seus entes queridos, perde a casa, as roupas, tudo, literalmente tudo que você possui: será um homem vazio, reduzido ao sofrimento e à necessidade, sem dignidade e juízo, porque quem perdeu tudo facilmente se perde a si mesmo (Levi, 1988, p. 28).

Judite sofreu várias perdas devido à guerra: a morte de seus avós, a casa de sua família em Belgrado, os pertences que foram ficando pelo caminho nas diversas fugas, o controle sobre seu próprio destino. Ao recordar esses fatos, a entrevistada é conduzida pelo fio condutor da memória à sua identificação com o judaísmo, que vem, portanto, pela empatia e de um sentimento de solidariedade para com os judeus a quem, como ela, tantas perdas foram impostas. 


\section{Para não cair no esquecimento}

Analisamos alguns dos aspectos mais significativos na memória oral de Judite quanto à sua experiência da Guerra. Constatou-se a presença de uma memória coletiva nacionalista, mediando a lembrança de Judite sobre a invasão da Iugoslávia pela Alemanha. Também se analisou, com base no conceito de memória-hábito, que a vivência traumática de Judite nos campos de concentração ficou, de algum modo, registrada em seu corpo, apesar de negada em sua lembrança. Outro ponto analisado foi a relação da memória com os valores do sujeito, a partir dos quais, ao mesmo tempo em que lembra, reflete e julga o passado. Nesse sentido, analisou-se o ateísmo de Judite e seu desligamento do socialismo como consequências de seu juízo ético sobre seu passado na guerra.

A partir de uma perspectiva dialética, reconheceram-se as contradições da memória, as quais, em Judite, apresentaram-se em sua lembrança ambivalente em relação aos italianos e à Europa. As ambiguidades da memória foram analisadas a partir de fatores ideológicos, sobretudo sua condição de classe. Finalmente, a memória revelou-se como uma categoria fundamental na compreensão da constituição da identidade da entrevistada, pois foi enquanto testemunha ocular e vivencial da Segunda Guerra que se produziu sua identificação com o coletivo judaico, destacando-se a questão da alteridade nesse processo.

A história de Judite se constrói como um trabalho sobre o tempo, na interseção entre a memória coletiva e a memória individual da guerra, como síntese inacabada que se constitui na apropriação singular que a entrevistada faz dos significados socialmente compartilhados acerca dos fatos de seu passado. É tarefa da Psicologia social compreender a imbricação dessas duas dimensões, que constituem cada pessoa como singular e, ao mesmo tempo, como "um agregado de relações sociais encarnadas num indivíduo" (Vygotski, 2000, p. 33).

O estudo realizado confirma a importância dos estudos da memória para a Psicologia social, pois, por meio dessa categoria de análise, pudemos compreender a constituição do sujeito, na sociedade em que está inserido e como protagonista da História. É raro encontrarmos ainda hoje vítimas dos horrores da Segunda Guerra Mundial que tenham sobrevivido para dela nos dar seu testemunho. Daí o valor do depoimento de uma pessoa como Judite e a contribuição deste trabalho, para não deixar cair no esquecimento esse triste capítulo de nossa História. 


\section{Referências}

Asch, S. E. (1966). Psicologia social. (2. ed., v. 2). São Paulo: Companhia Editora Nacional.

Bosi, A. (1992). Dialética da colonização. São Paulo: Companhia das Letras.

Bosi, E. (2003). O tempo vivo da memória: ensaios de Psicologia social. (2. ed.). São Paulo: Ateliê.

Bonder, N. \& Sorj, B. (2001). Judaísmo para o século XXI. Rio de Janeiro: Jorge Zahar.

Chauí, M. S. (1984). O que é ideologia? São Paulo: Abril Cultural/ Brasiliense.

Ciampa, A. C. (1998). Identidade humana como metamorfose: a questão da família e do trabalho e a crise de sentido do mundo moderno. Interaçôes, 3 (6), 87-101.

Crochik, J. L. (2006). Preconceito, Individuo e Cultura. (3. ed.). São Paulo: Casa do Psicólogo.

Finkielkaut, A. (1981). El judío imaginario. (J. Jordá trad.). Barcelona: Anagrama.

Haesbaert, R. (2004). O mito da desterritorialização: do fim dos territórios à multiterritorialidade. Rio de Janeiro: Bertrand Brasil.

Heller, A. (2000). O cotidiano e a História. São Paulo: Paz e Terra.

Horkheimer, M. \& Adorno, T. (1978). Temas Básicos da Sociología. (2. ed.). São Paulo: Cultrix.

Levi, P. (1988). Si esto es un hombre. Buenos Aires: Mila.

Memmi, A. (1970). Retrato de um judeu. In: J. Guinsburg (org). O judeu e a Modernidade. (pp. 595-605). São Paulo: Perspectiva.

Paxton, R. O. (2007). A anatomia do fascismo. São Paulo: Paz e Terra.

Pollak, M. (1989). Memória, esquecimento, silêncio. (v. 2). Rio de Janeiro: Estudos Históricos.

Sartre, J. P. (1995). Reflexōes sobre o racismo: a questão judaica. São Paulo: Ática. 
Schucman, L. V. (2006). Produção de sentidos e a construção da identidade judaica em Florianópolis. Dissertação de mestrado, Programa de Pós-graduação em Psicologia, Universidade Federal de Santa Catarina, Florianópolis.

Schwarcz, L. M. (1993). O espetáculo das raças: cientistas, instituiçōes e a questão racial no Brasil. São Paulo: Companhia das Letras.

Santos, B. S. (1995). Pela mão de Alice: o social e o político na Pós-modernidade. São Paulo: Cortez.

Szymanski, H. (2000). Entrevista reflexiva: um olhar psicológico para a entrevista em pesquisa. Psicologia da Educação, 10 (11), 193-215.

Vygotsky, L. S. (1996). Teoria e método em Psicologia. São Paulo: Martin Fontes.

Vygotsky, L. S. (2000). A construção do pensamento e da linguagem. São Paulo: Martins Fontes. 